\title{
DESKRIPSI KEMAMPUAN BERPIKIR KRITIS SISWA KELAS VII SMP DALAM MENYELESAIKAN MASALAH MATEMATIKA MELALUI TIPE SOAL OPEN- ENDED PADA MATERI PECAHAN
}

\author{
Yoseffin Dhian Crismasanti \\ 202013018@student.uksw.edu \\ Program Studi Pendidikan Matematika \\ Universitas Kristen Satya Wacana \\ Tri Nova Hasti Yunianta \\ trinova.yunianta@staff.uksw.edu \\ Program Studi Pendidikan Matematika \\ Universitas Kristen Satya Wacana
}

\begin{abstract}
ABSTRAK
Selama ini kecenderungan para siswa hanya terfokus pada hafalan rumus matematika dengan menghafalkan rumus dianggap bisa menemukan solusi dari permasalahan. Padahal, hal itu belum tentu bisa terealisasikan. Hal ini menyebabkan kemampuan berpikir kritis siswa tidak berkembang secara optimal. Penelitian ini bertujuan untuk mendeskripsikan kemampuan berpikir kritis siswa dalam memecahkan masalah matematika melalui tipe soal open-ended pada materi pecahan kelas VII SMP Negeri 2 Tuntang. Penelitian ini merupakan penelitian deskriptif kualitatif. Penentuan subjek dalam penelitian ini menggunakan teknik purposive sampling yaitu 3 siswa kelas VII dengan kemampuan matematika tinggi. Teknik pengumpulan data pada penelitian ini adalah menggunakan teknik tes tertulis kemampuan berpikir kritis, wawancara dan pengamatan serta dokumentasi. Berdasarkan analisis data, dapat disimpulkan bahwa subjek FD memiliki kemampuan berpikir kritis yang konsisten karena pada ketiga soal yang diberikan subjek FD mampu melalui 5 tahapan berpikir kritis dengan baik yaitu pada tahap strategies and tactics. Subjek AB pada soal nomor 1 melalui tahapan strategies and tactics. Namun pada soal nomor 2 hanya mencapai tahap advanced clarification dan soal nomor 3 pada tahap basic support. Subjek EK memiliki kemampuan berpikir kritis pada tahap basic support pada soal nomor 1 dan 3, sedangkan pada soal nomor 2 hanya mencapai pada tahap advanced clarification. Hasil-hasil ini menunjukkan adanya perbedaan kemampuan berpikir kritis siswa pada level pendidikan dan kemampuan matematika yang sama. Tulisan ini diharapkan dapat memberi sumbangan pengetahuan bagi guru tentang kemampuan berpikir kritis siswa SMP dalam memecahkan masalah matematika melalui tipe soal open-ended pada materi pecahan dan bagi siswa untuk lebih meningkatkan kemampuan berpikr kritis.
\end{abstract}

Kata kunci: berpikir kritis, open-ended, pecahan

\section{PENDAHULUAN}

Matematika merupakan salah satu bidang studi yang dipelajari di semua jenjang pendidikan. Menurut Suherman (2001: 21) matematika diajarkan bukan hanya untuk mengajarkan keterampilan berhitung, kete- rampilan mengerjakan soal, bukan hanya aspek praktis yang dikejar, tetapi matematika mengajarkan aspek-aspek lain berupa kecermatan, ketelitian, berpikir logis, kritis, praktis, bersikap positif dan berjiwa kreatif serta bertanggungjawab. Memandang arti 
penting matematika, maka sudah selayaknya jika setiap siswa harus memiliki kemampuan untuk menguasai matematika.

Salah satu kemampuan yang perlu ditumbuhkan siswa sejak dini adalah kemampuan berpikir kritis, karena dengan kemampuan berpikir kritis dapat meningkatkan pemahaman konsep serta dapat mengembangkan kemampuan berpikir siswa untuk menyelesaikan suatu permasalahan khususnya dalam pembelajaran matematika. Pada saat mengerjakan soal matematika siswa tidak terlepas dari proses berpikir, dimana siswa berusaha mencari cara bagaimana ia dapat menyelesaikan dan mencari solusi dari permasalahan matematika tersebut. Berdasarkan hasil pengamatan Nurannisa (2013) menyatakan bahwa siswa mempelajari matematika hanya sesuai dengan apa yang diajarkan oleh guru, yaitu lebih prosedural. Selain itu selama ini kecenderungan para siswa hanya terfokus pada hafalan rumus, mereka berpikir hanya dengan menghafalkan rumus bisa menemukan solusi dari permasalahan. Padahal, hal itu belum tentu bisa terealisasikan. Hal ini menyebabkan kemampuan berpikir kritis siswa tidak berkembang secara optimal.

Kenyataan yang terjadi saat ini kemampuan siswa dalam pembelajaran matematika masih belum optimal. Hal ini dikarenakan siswa hanya mencontoh apa yang dikerjakan guru, dan dalam menyelesaikan soal, siswa beranggapan cukup dikerjakan seperti apa yang dicontohkan (Mina, 2006: 4). Akibatnya siswa kurang memiliki kemampuan menyelesaikan soal dengan alternatif lain. Siswa juga kurang memperoleh kesempatan secara bebas untuk mengekspresikan dirinya. Padahal kemampuan seperti ini sangat dibutuhkan oleh siswa untuk menyelesaikan permasalahan-permasalahan yang akan mereka hadapi dimasa depan. Berdasarkan pendapat tersebut dalam pembelajaran matematika hendaknya dapat memberikan keleluasaan kepada siswa untuk berpikir secara aktif dan kreatif, yang salah satunya adalah pembelajaran dengan pemberian soal-soal open-ended.

Salah satu materi pembelajaran matematika yang berpotensi sebagai sarana untuk mengembangkan kemampuan berpikir kritis adalah materi pecahan, materi pecahan adalah materi yang dekat dengan siswa, karena berkaitan dalam kehidupan seharihari. Tujuan pembelajaran pokok bahasan pecahan adalah siswa dapat menyelesaikan soal yang berkaitan dengan operasi hitung pecahan serta menggunakannya dalam pemecahan masalah.

Menurut hasil penelitian yang dilakukan oleh Hidayanti (2016) dalam skripsinya yang berjudul "Analisis Kemampuan Berpikir Kritis Siswa SMP Kelas IX Pada Materi Kesebangunan” Berdasarkan hasil analisis data pada sub bab hasil dan pembahan dapat disimpulkan bahwa kemampuan berpikir kritis siswa SMP kelas IX masih tergolong rendah. Hal tersebut dikarenakan siswa yang memenuhi masingmasing indikator kemampuan berpikir kritis masih di bawah 50\%. Terutama pada indikator analisis, evaluasi, dan inferensi analisis yang terlihat masih sangat rendah. Kondisi yang seperti ini dikarenakan konsep kese-bangunan siswa belum optimal, siswa terburu-buru mengambil kesimpulan tanpa melakukan analisis terlebih dahulu.

Tujuan dari penelitian ini adalah untuk mendeskripsikan kemampuan berpikir kritis siswa dalam menyelesaikan masalah matematika pada materi pecahan melalui tipe soal open-ended di SMP Negeri 2 Tuntang. 


\section{KAJIAN PUSTAKA}

\section{Berpikir Kritis}

Berpikir sebagai kemampuan mental dapat dibedakan menjadi beberapa jenis antara lain berpikir logis, analitis, sistematis, kritis dan kreatif. Berpikir kritis merupakan perwujudan dari berpikir tingkat tinggi (higher order thinking). Di mana berpikir kritis dapat dipandang sebagai kemampuan berpikir untuk membandingkan dua atau lebih informasi dan bisa menyimpulkannya dengan penuh pertimbangan, kejelasan serta dapat mengevaluasi dari apa yang telah didapatkan dari pemikiran tersebut.

Berpikir kritis digunakan pada proses dasar dalam berpikir untuk menganalisis pendapat dan memberikan ide dari masingmasing arti dan interpretasi, untuk mengembangkan sebuah pola kohesif dan penalaran logis, untuk memahami peletakan asumsi dan bias pada setiap posisi, sama halnya menyiapkan sebuah model presentasi yang dapat dipercaya, ringkas dan meyakinkan (Ennis, 1995). Hal ini juga didukung oleh pendapat Johnson (2010: 183) berpikir kritis merupakan sebuah proses terarah dan jelas yang digunakan dalam kegiatan mental seperti memecahkan masalah, mengambil keputusan, membujuk, menganalisis asumsi, dan melakukan penelitian ilmiah. Kemampuan berpikir kritis sangatlah penting dalam proses pembelajaran matematika, oleh karena itu guru harus mendorong siswa untuk memperluas pemikiran mereka dengan membuat ide-ide baru dan memotivasi untuk menggali topik lebih dalam dan berusaha untuk memecahkan masalah (Santrock, 2014).

Robert Ennis (1995) mengidentifikasi kemampuan berpikir kritis menjadi 12 indikator yang dikelompokkannya dalam lima besar aktivitas, yaitu sebagai berikut: 1) Memberikan penjelasan sederhana (elementary clarification); 2) Membangun keterampilan dasar (basic support); 3) Menyimpulkan (inference); 4) Membuat penjelasan lanjut (advanced clarification); 5) Mengatur strategi dan taktik (strategy and tactics).Adapun Indikator dalam setiap tahapannya dapat dilihat pada Tabel 1 .

Tabel 1 Indikator Kemampuan Berpikir Kritis Menurut Ennis

\begin{tabular}{|c|c|c|}
\hline Langkah & Keterampilan Berpikir Kritis & Indikator \\
\hline 1 & $\begin{array}{l}\text { Memberikan Penjelasan Sederhana } \\
\text { (Elementary Clarification) }\end{array}$ & $\begin{array}{l}\text { 1. Memfokuskan pertanyaan } \\
\text { 2. Menganalisis argumen } \\
\text { 3. } \\
\text { Bertanya dan menjawab pertanyaan klarifikasi }\end{array}$ \\
\hline 2 & $\begin{array}{l}\text { Membangun Keterampilan Dasar } \\
\text { (Basic Support) }\end{array}$ & $\begin{array}{l}\text { 4. } \begin{array}{l}\text { Mempertimbangkan apakah sumber dapat dipercaya } \\
\text { atau tidak }\end{array} \\
\text { 5. } \begin{array}{l}\text { Mengobservasi dan mempertimbangkan hasil } \\
\text { observasi }\end{array}\end{array}$ \\
\hline 3 & Menyimpulkan (Inference) & 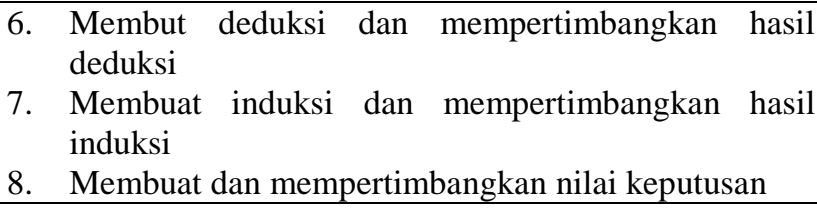 \\
\hline 4 & $\begin{array}{lr}\text { Membuat } & \text { Penjelasan } \\
\text { (Advanced Clarification) }\end{array}$ & 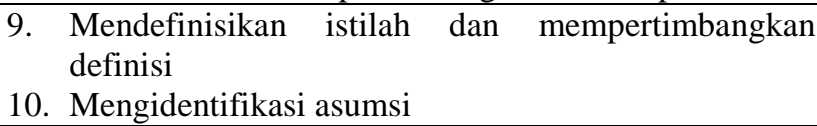 \\
\hline 5 & $\begin{array}{l}\text { Strategi dan taktik } \\
\text { (Strategies and Tactics) }\end{array}$ & $\begin{array}{l}\text { 11. Menentukan tindakan } \\
\text { 12. Berinteraksi dengan orang lain }\end{array}$ \\
\hline
\end{tabular}




\section{Open-Ended}

Menurut Takahashi (2006), soal terbuka (open-ended) adalah soal yang mempunyai banyak solusi atau strategi penyelesaian. Hal ini sesuai dengan pendapat Shimada dan Becker (1997) bahwa pembelajaran open-ended adalah pembelajaran yang menyajikan suatu permasalahan yang memiliki metode atau penyelesaian yang benar lebih dari satu. Pembelajaran openended dapat memberi kesempatan kepada siswa untuk memperoleh pengetahuan/ pengalaman menemukan, mengenali, dan memecahkan masalah dengan beragam teknik.

Menurut Takahashi (2006), terdapat beberapa manfaat dari penggunaan soal terbuka dalam pembelajaran matematika, yaitu sebagai berikut.

1. Siswa menjadi lebih aktif dalam mengekspresikan ide-ide mereka.

2. Siswa mempunyai kesempatan lebih untuk secara komprehensif menggunakan pengetahuan dan keterampilan mereka.

3. Siswa mempunyai pengalaman yang kaya dalam proses menemukan dan menerima persetujuan dari siswa lain terhadap ide-ide mereka.

Dalam pembelajaran matematika, soal dengan tipe open-ended hendaknya diberikan kepada siswa. Dengan cara ini siswa mempunyai pengalaman dalam menemukan sesuatu selama proses pemecahan masalah. Aktivitas matematika yang dihasilkan atau dibangun berdasarkan soal open ended akan sangat kaya sedemikian sehingga guru dapat mengevaluasi keterampilan berpikir kritis siswa.

\section{Pecahan}

Salah satu materi pembelajaran matematika yang berpotensi sebagai sarana untuk mengembangkan kemampuan berpikir kritis adalah materi pecahan, materi pecahan adalah materi yang dekat dengan siswa, karena berkaitan dalam kehidupan seharihari. Tujuan pembelajaran pokok bahasan bilangan pecahan, adalah siswa dapat menyelesaikan soal yang berkaitan dengan operasi hitung pecahan serta menggunakannya dalam pemecahan masalah. Pembahasan materi pecahan secara formal dipelajari di sekolah dasar sejak kelas III semester 2 dengan penekanan pada pengembangan konsep dasar bilangan pecahan melalui benda-benda konkret kemudian dengan model-model atau gambar. Sementara di sekolah menengah, materi pecahan kembali dibahas pada kelas VII semester 1 dengan penekanan pada melatih cara berpikir dan bernalar serta mengembangkan kemampuan memecahkan masalah mengenai bilangan pecahan yang berkaitan dengan kehidupan sehari-hari (Wicaksono, 2013).

\section{METODE PENELITIAN}

Penelitian ini merupakan penelitian deskriptif kualitatif. Penelitian deskriptif adalah penelitian yang dilakukan untuk menggambarkan atau menjelaskan secara sistematis, faktual dan akurat mengenai sifat populasi tertentu, dengan kata lain peneliti hendak menggambarkan suatu gejala (fenomena), atau sifat tertentu, mencari atau menerangkan keterkaitan antar variabel (Sanjaya, 2013: 59). Pada penelitian ini peneliti hendak mendeskripsikan kemampuan berpikir kritis siswa kelas VII dalam menyelesaikan masalah matematika melalui tipe soal open ended pada materi pecahan. 
Penelitian ini dilaksanakan di SMP Negeri 2 Tuntang pada tahun ajaran 2016/2017. Penentuan subjek dalam penelitian ini menggunakan teknik purposive sampling yaitu 3 siswa kelas VII dengan kemampuan matematika tinggi. Peneliti mengambil subjek dengan kemampuan tinggi yaitu dengan interval nilai 85-100, agar subjek mempunyai kemampuan awal matematika yang sama. Adapun pemilihan subjek tersebut dengan pertimbangan tertentu yaitu, subjek memiliki kemampuan matematika tinggi berdasarkan nilai UTS dan UAS serta merupakan subjek merupakan siswa yang mudah dalam berkomunikasi. Adapun dasar pertimbangan pemilihan subjek dapat dilihat pada Tabel 2.

Tabel 2. Kriteria Pemilihan Subjek

\begin{tabular}{cccccc}
\hline Subjek & Kode Subjek & Nilai UTS & Nilai UAS & $\begin{array}{c}\text { Rata-Rata } \\
\text { Nilai }\end{array}$ & $\begin{array}{c}\text { Kemampuan } \\
\text { Matematika }\end{array}$ \\
\hline Subjek 1 & FD & 90 & 92,5 & 91,25 & Tinggi \\
Subjek 2 & AB & 88 & 85 & 86,5 & Tinggi \\
Subjek 3 & EK & 85 & 90 & 87,5 & Tinggi \\
\hline Teknik & pengumpulan & data pada & \multicolumn{2}{c}{ pengumpulan data berlangsung dan setelah }
\end{tabular}

penelitian ini adalah menggunakan teknik tes tertulis kemampuan berpikir kritis, wawancara dan pengamatan serta dokumentasi. Pada teknik tes tertulis peneliti menggunakan soal uraian dengan tipe soal open-ended sebanyak 3 butir soal. Instrumen utama dalam penelitian ini adalah peneliti sendiri. Peneliti sebagai instrumen utama dibantu dengan instrumen lainnya yaitu soal tes berpikir kritis, pedoman wawancara, kisikisi instrumen soal dan tahapan serta indikator berpikir kritis.

Teknik validasi data yang dilakukan dalam penelitian ini menggunakan teknik triangulasi teknik. Triangulasi teknik adalah menguji kredibilitas data dilakukan dengan cara mengecek data yang kepada sumber yang sama dengan teknik yang berbeda Teknik ini diperoleh dengan melakukan observasi, wawancara dan dokumentasi (Sugiyono, 2010: 373).

Analisis data dalam penelitian kualitatif sudah dilakukan sejak pengumpulan data berlangsung dan setelah pengumpulan data dalam periode tertentu. Miles dan Huberman dalam Sugiyono (2010: 337) mengemukakan bahwa aktivitas dalam analisis data kualitatif dilakukan secara interaktif dan berlangsung secara terus menerus sampai tuntas, sehingga datanya sudah jenuh. Aktivitas dalam analisis data yaitu: 1) reduksi data; 2) penyajian data; dan 3) penarikan kesimpulan dan verifikasi.

\section{HASIL PENELITIAN DAN PEMBAHASAN}

Berdasarkan hasil analisis terhadap hasil tes dan wawancara, diperoleh bahwa kemampuan berpikir kritis setiap subjek melampaui tahapan yang berbeda pada setiap soal yang diberikan. Adapun untuk mengukur kemampuan berpikir kritis yang dimiliki setiap subjek diukur dengan menggunakan indikator kemampuan berpikir kritis yang dapat dilihat pada Tabel 3. 


\section{Soal 1}

Tabel 3 Rangkuman Kemampuan Berpikir Kritis Setiap Subjek

\begin{tabular}{|c|c|c|c|c|c|c|c|c|c|c|}
\hline \multirow{3}{*}{$\begin{array}{c}\text { Kemampuan } \\
\text { Berpikir } \\
\text { Kritis }\end{array}$} & \multirow{3}{*}{ Indikator } & \multicolumn{9}{|c|}{ Nomor Soal } \\
\hline & & \multicolumn{3}{|c|}{$\begin{array}{l}\text { Subjek } \\
\text { FD }\end{array}$} & \multicolumn{3}{|c|}{$\begin{array}{c}\text { Subjek } \\
\text { AB }\end{array}$} & \multicolumn{3}{|c|}{$\begin{array}{l}\text { Subjek } \\
\text { EK }\end{array}$} \\
\hline & & 1 & 2 & 3 & 1 & 2 & 3 & 1 & 2 & 3 \\
\hline \multirow{3}{*}{$\begin{array}{l}\text { Elementary } \\
\text { Clarification }\end{array}$} & 1. Memfokuskan pertanyaan & $\checkmark$ & $\checkmark$ & $\checkmark$ & $\checkmark$ & $\checkmark$ & $\checkmark$ & $\checkmark$ & $\checkmark$ & $\checkmark$ \\
\hline & 2. Menganalisis argumen & $\checkmark$ & $\checkmark$ & $\checkmark$ & $\checkmark$ & $\checkmark$ & $\checkmark$ & $\checkmark$ & $\checkmark$ & $\checkmark$ \\
\hline & 3. Bertanya dan menjawab pertanyaan klarifikasi & $\checkmark$ & $\checkmark$ & $\checkmark$ & $\checkmark$ & $\checkmark$ & $\checkmark$ & $\checkmark$ & $\checkmark$ & $\checkmark$ \\
\hline \multirow{3}{*}{$\begin{array}{c}\text { Kemampuan } \\
\text { Berpikir } \\
\text { Kritis }\end{array}$} & \multirow{3}{*}{ Indikator } & \multicolumn{9}{|c|}{ Nomor Soal } \\
\hline & & \multicolumn{3}{|c|}{$\begin{array}{l}\text { Subjek } \\
\text { FD }\end{array}$} & \multicolumn{3}{|c|}{$\begin{array}{l}\text { Subjek } \\
\text { AB }\end{array}$} & \multicolumn{3}{|c|}{$\begin{array}{l}\text { Subjek } \\
\text { EK }\end{array}$} \\
\hline & & 1 & 2 & 3 & 1 & 2 & 3 & 1 & 2 & 3 \\
\hline \multirow[t]{2}{*}{ Basic Support } & $\begin{array}{l}\text { 4. Mempertimbangkan apakah sumber dapat } \\
\text { dipercaya atau tidak }\end{array}$ & $\checkmark$ & $\checkmark$ & $\checkmark$ & $\checkmark$ & $\checkmark$ & $\checkmark$ & $\checkmark$ & $\checkmark$ & $\checkmark$ \\
\hline & $\begin{array}{l}\text { 5. Mengobservasi dan mempertimbangkan hasil } \\
\text { observasi }\end{array}$ & $\checkmark$ & $\checkmark$ & $\checkmark$ & $\checkmark$ & $\checkmark$ & $\checkmark$ & $\checkmark$ & $\checkmark$ & $\checkmark$ \\
\hline \multirow[t]{3}{*}{ Inference } & $\begin{array}{l}\text { 6. Membuat deduksi dan mempertimbangkan } \\
\text { hasil deduksi }\end{array}$ & $\checkmark$ & $\checkmark$ & $\checkmark$ & $\checkmark$ & $\checkmark$ & $x$ & $x$ & $\checkmark$ & $x$ \\
\hline & $\begin{array}{l}\text { 7. Membuat induksi dan mempertimbangkan } \\
\text { hasil induksi }\end{array}$ & $\checkmark$ & $\checkmark$ & $\checkmark$ & $\checkmark$ & $\checkmark$ & $x$ & $x$ & $\checkmark$ & $x$ \\
\hline & $\begin{array}{l}\text { 8. Membuat dan mempertimbangkan nilai } \\
\text { keputusan }\end{array}$ & $\checkmark$ & $\checkmark$ & $\checkmark$ & $\checkmark$ & $\checkmark$ & $x$ & $x$ & $\checkmark$ & $x$ \\
\hline \multirow[t]{2}{*}{$\begin{array}{c}\text { Advanced } \\
\text { Clarification }\end{array}$} & $\begin{array}{l}\text { 9. Mendefinisikan istilah dan mempertimbangkan } \\
\text { definisi }\end{array}$ & $\checkmark$ & $\checkmark$ & $\checkmark$ & $\checkmark$ & $\checkmark$ & $x$ & $x$ & $\checkmark$ & $x$ \\
\hline & 10. Mengidentifikasi asumsi & $\checkmark$ & $\checkmark$ & $\checkmark$ & $\checkmark$ & $\checkmark$ & $x$ & $x$ & $\sqrt{ }$ & $x$ \\
\hline \multirow{2}{*}{$\begin{array}{l}\text { Strategies and } \\
\text { Ttactic }\end{array}$} & 11. Menentukan tindakan & $\checkmark$ & $\checkmark$ & $\checkmark$ & $\checkmark$ & $x$ & $x$ & $x$ & $x$ & $x$ \\
\hline & 12. Berinteraksi dengan orang lain & $\checkmark$ & $\checkmark$ & $\checkmark$ & $\checkmark$ & $x$ & $x$ & $x$ & $x$ & $x$ \\
\hline
\end{tabular}

\section{Catatan:}

Tanda $\checkmark$ menyatakan bahwa jawaban siswa memenuhi pada indikator yang diteliti.

Tanda $\boldsymbol{x}$ menyatakan bahwa jawaban siswa tidak memenuhi pada indikator yang diteliti.

Siswa dinyatakan meliliki kemampuan berpikir kritis jika memenuhi semua indikator yang diteliti.

Soal nomor satu, dari hasil analisis yang dilakukan subjek $\mathrm{FD}$ dan $\mathrm{AB}$ dapat melampaui semua tahapan berpikir kritis yaitu pada tahap strategies and tactics dan subjek EK hanya sampai pada tahapan berpikir kritis yang kedua yaitu basic support.

Subjek FD dan AB dapat melalui 5 tahapan berpikir kritis pada soal nomor 1 . Pada tahap elementary clarification subjek FD dan AB mampu memfokuskan pertanyaan dengan memberikan analisis argumen dengan cermat. Pada tahapan basic support subjek mampu menganalisis masalah dengan mengidentifikasi informasi yang relevan serta mempertimbangkan dugaan kemungkinan jawaban dengan tepat. Selanjutnya pada tahap inference subjek dapat menemukan solusi/alternatif jawaban lainnya dan menarik kesimpulan dengan benar. Tahap selanjutnya advanced clarification subjek mampu menjelaskan dengan baik hasil dari observasi dan kesimpulannya dengan lancar dan jelas. Pada tahap ini subjek memaparkan hasil jawabannya bahwa takaran yang paling sedikit adalah 6 takaran yaitu 5 takaran dengan ukuran $\frac{3}{4} \mathrm{~kg}$ dan 1 takaran berukuran $\frac{1}{2} \mathrm{~kg}$. Tahap yang terakhir yaitu strategies 
and tactics subjek menyimpulkan hasil dari alternatif jawaban yang cocok sebagai kesimpulan akhir dalam proses penyelidikan-

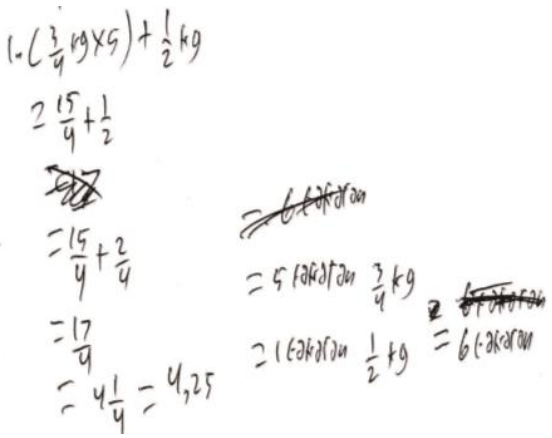

Subjek FD nya. Adapaun hasil pekerjaan subjek FD dan $\mathrm{AB}$ dapat dilihat pada Gambar 1 .

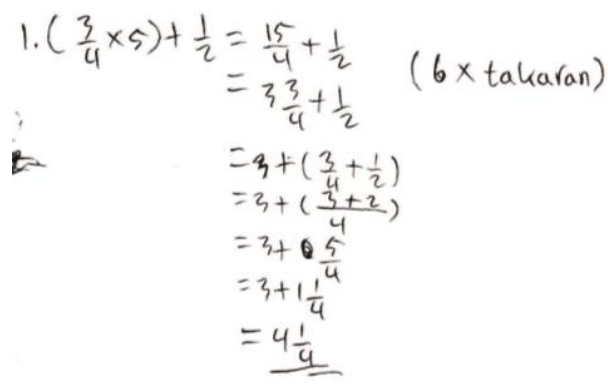

Subjek $A B$

Gambar 1 Pekerjaan Subjek FD dan AB pada Soal Nomor 1

Selanjutnya subjek EK pada soal nomor satu hanya sampai pada tahapan yang kedua yaitu basic support. Pada tahap pertama yaitu elementary clarification, subjek mampu mengidentifikasi masalah dengan baik yaitu dengan menyebutkan fokus pertanyaan mencari jumlah takaran yang paling sedikit. Kemudian pada tahap basic support subjek mulai menganalisis masalah dengan menggunakan sumber informasi yang sesuai yaitu dengan cara menakar menggunakan takaran berukuran $\frac{1}{2}$ sebanyak 4 kali dan $\frac{3}{4}$ sebanyak 3 kali, sehingga jumlah takaran yang berhasil ditemukan subjek adalah 7 takaran. Jawaban subjek ini memang benar, jawaban merupakan salah satu alternatif cara untuk menakar. Namun jawaban subjek tidak sesuai dengan pertanyaan yang diminta dan bukan merupakan kesimpulan jawaban yang tepat, sehingga pada tahap selanjutnya subjek tidak mampu menyimpulkan dengan benar dan tahapan berpikir kritisnya hanya pada basic support. Adapun pekerjaan subjek EK dapat dilihat pada Gambar 2.

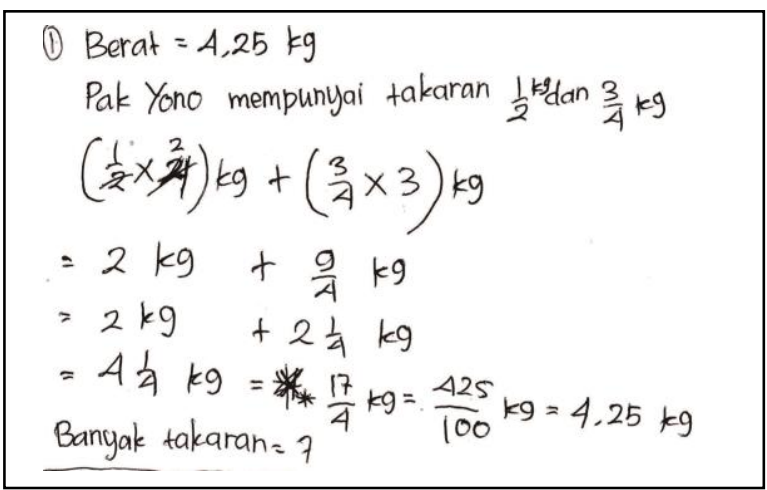

Gambar 2 Pekerjaan Subjek EK pada Soal Nomor 1

\section{Soal 2}

Soal nomor dua, dari hasil analisis yang dilakukan subjek FD dapat melalui semua tahapan berpikir kritis yaitu pada tahap strategies and tactic. Sementara subjek $\mathrm{AB}$ dan EK hanya sampai pada tahapan berpikir kritis yang keempat yaitu advanced clarification. 
Subjek FD sampai pada tahapan yang tertinggi yaitu strategies and tactics. Subjek dapat melalui tahap elementary clarification dengan memfokuskan pertanyaannya serta dapat menjaga kondisi berpikir dengan baik. Pada tahap basic support subjek dapat melaporkan dugaan untuk mengerjakan langkah penyelesaian serta melakukan observasi berdasarkan hasil pengamatannya dengan selang waktu yang cepat. Pada tahap inference Subjek dapat membuat dan mempertimbangkan hasil kesimpulan dan menentukan alternatif jawaban lain. Pada saat tes subjek mengerjakan dengan mencari 1 bagian pizza terlebih dahulu, namun saat

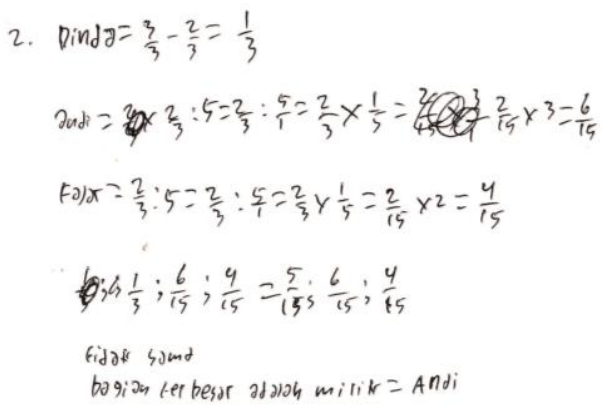

wawancara dilakukan subjek memaparkan hasil jawabannya dengan mengalikan perbandingan pecahannya. Pada tahap advanced clarification Subjek dapat memberikan penjelasan lanjut mengenai hasil penyelesaian yang telah ia peroleh bahwa bagian yang didapatkan tidak sama andi lah yang mendapat bagian paling banyak. Tahap strategies and tactics subjek memaparkan kesimpulan dan alternatif jawaban yang sesuai. Adapaun hasil pekerjaan subjek FD dan alternatif penyelesaian lain yang diperoleh dapat dilihat pada Gambar 3

$$
\begin{aligned}
& \text { 2. Dindz }=\frac{3}{3}-\frac{z}{3}=\frac{1}{3}=\frac{5}{15} \\
& \text { andi }-\frac{2}{3} \times \frac{3}{4}=\frac{6}{15} \\
& \text { Indi }=\frac{2}{3}: \frac{5}{1}=\frac{2}{3} \times \frac{1}{5}=\frac{2}{15} \times 3=\frac{6}{15} \\
& \text { (F) } x=\frac{2}{3} x^{2}=\frac{4}{5}
\end{aligned}
$$

Gambar 3 Hasil Pekerjaan Subjek FD dan Alternatif Jawaban pada Soal Nomor 2

Selanjutnya subjek AB dan EK pada soal nomor 2 hanya sampai pada tahapan berpikir kritis yang keempat yaitu advanced clarification. Pada tahap elementary clarification subjek $\mathrm{AB}$ dan EK mampu memahami masalah dengan menyebutkan pertanyaan apa yang diminta dari soal. Pada tahap basic support subjek mulai menafsir kemungkinan langkah penyelesaian yang akan digunakan yaitu dengan mencari bagian pizza dinda terlebih dahulu, lalu mencari bagian Andi dan Fajar. Pada tahap inference subjek AB mulai memutuskan kesimpulan untuk mencari bagian yang terbesar dengan cara mengubah pecahan menjadi desimal atau pun persen, sementara subjek EK mengubah pencahan dengan menyamakan peyebutnya. Lalu pada tahap advanced clarification subjek mampu memberikan penjelasan lanjut bahwa Andi yang mendapat bagian pizza paling banyak. Pada tahap strategies and tactics subjek AB dan EK tidak melampaui tahapan ini karena subjek hanya menemukan satu alternatif jawaban. Adapaun hasil subjek $\mathrm{AB}$ dan EK dapat dilihat pada Gambar 4. 


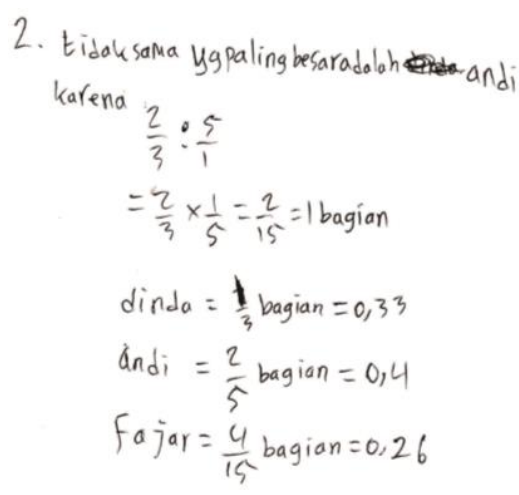

Subjek $A B$

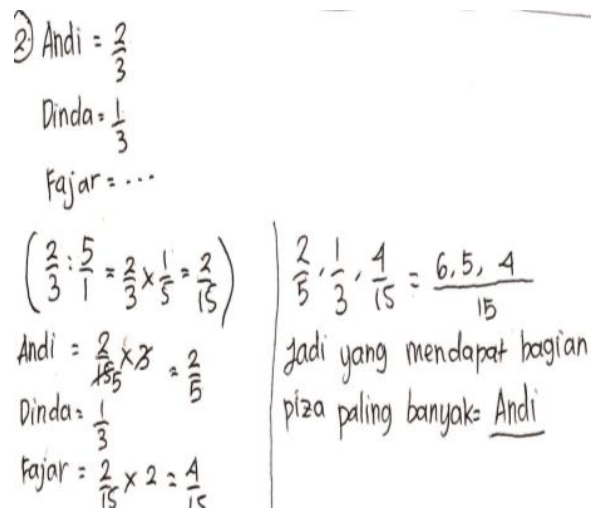

Subjek $\boldsymbol{E K}$

\section{Soal 3 \\ Soal 3}

Gambar 4 Hasil Pekerjaan Subjek AB dan EK pada Soal Nomor 2
Soal nomor tiga, dari hasil analisis yang dilakukan subjek FD dapat melalui 5 tahapan berpikir kritis yaitu pada tahap tertinggi strategies and tactics. Sementara subjek $A B$ dan $E K$ hanya sampai pada tahapan berpikir kritis yang kedua yaitu pada tahap basic support.

Subjek FD pada tahap elementary clarification subjek dapat memahami masalah dengan memberikan tanda yang sesuai. Pada tahap basic support subjek dapat melaporkan dugaan untuk mengerjakan langkah penyelesaian serta melakukan observasi berdasarkan hasil pengamatannya dengan selang waktu yang cepat, subjek mengerjakan dengan cara menyamakan penyebutnya terlebih dahulu. Pada tahap inference Subjek dapat membuat dan mempertimbangkan hasil kesimpulan dan menentukan alternatif jawaban lain. Pada saat tes subjek mengerjakan dengan menyamakan penyebutnya, namun pada saat wawancara dilakukan subjek mampu memaparkan hasil jawabannya dengan cara menyampaikan bahwa terdapat pola atau bentuk yang sama. Pada tahap advanced clarification Subjek dapat memberikan penjelasan lanjut mengenai hasil penyelesaian yang telah ia peroleh dan pada tahap strategies and tactics subjek memaparkan kesimpulan dan alternatif jawaban yang sesuai dan paling cepat untuk jawaban yang ia peroleh. Adapun hasil pekerjaan dan cuplikan wawancara subjek FD dapat dilihat pada Gambar 5.

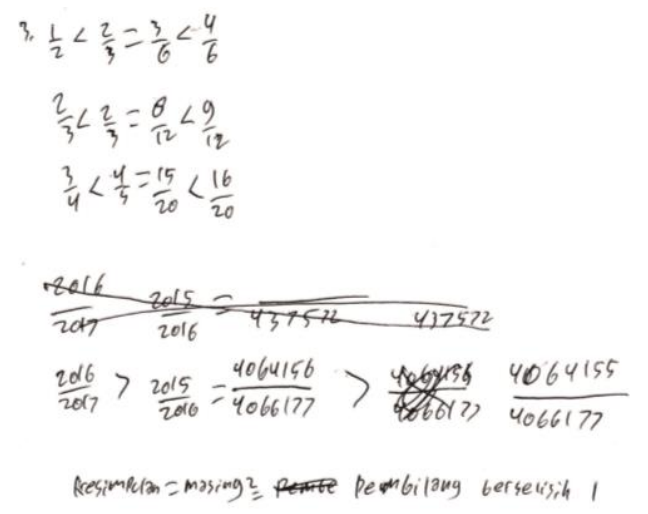

Gambar 5 Pekerjaan dan Cuplikan Wawancara Subjek FD Soal Nomor 3 
Selanjutnya subjek AB dan EK pada soal nomor 3 hanya sampai pada tahap kedua yaitu basic support. Pada tahap elementary clarification, subjek $\mathrm{AB}$ dan EK mampu memfokuskan pertanyaan dan menganalisis masalah dengan memberikan tanda yang sesuai. Lalu pada tahap basic support subjek $\mathrm{AB}$ mulai menghitung dengan cara mengubah pecahan menjadi bentuk desimal sehingga dapat memberikan tanda kurang dari.Sementara subjek EK dengan cara menyamakan penyebut-

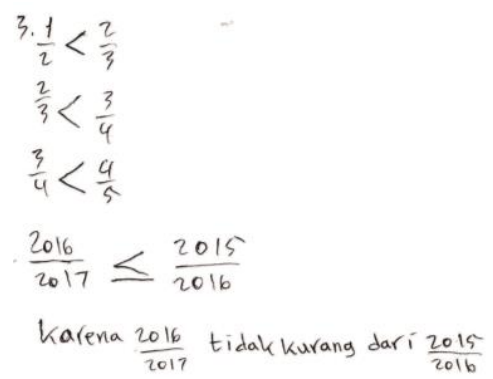

Subjek $\boldsymbol{A B}$ nya. Namun pada tahap inference yaitu pada soal $\frac{2016}{2017} \ldots \frac{2015}{2016}$ subjek memberikan kesimpulan yang kurang tepat dan kurang beralasan sehingga pada tahap selanjutnya yaitu advanced clarification dan strategies and tactics tentu saja tidak dilalui karena kesimpulan yang diberikan subjek tidak tepat. Adapun pekerjaan dan hasil cuplikan wawancara subjek $\mathrm{AB}$ dapat dilihat pada Gambar 6.

$$
\begin{aligned}
& \text { 3. } \frac{1}{2}<\frac{2}{3}=\frac{3<4}{6}=\frac{3}{6}<\frac{4}{6} \\
& \frac{2}{3}-<: \frac{3}{4}=\frac{8<9}{12}=\frac{8}{12}<\frac{9}{12} \\
& \frac{3}{4}<\frac{4}{5}=\frac{15<16}{20}=\frac{15}{20}<\frac{16}{20} \\
& \frac{2016}{2017}>\frac{2015}{2016}
\end{aligned}
$$

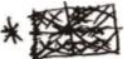

Gambar 6 Pekerjaan Subjek AB dan EK pada Soal Nomor 3

Temuan dalam penelitian ini yaitu dengan hasil belajar matematika yang tinggi, kemampuan berpikir kritisnya belum tentu sama. Hal ini tampak bahwa dengan kemampuan matematika tinggi, kemampuan berpikir kritis setiap subjek melalui tahapan yang berbeda. Kemudian ditemukan ada subjek (FD) memiliki kemampuan berpikir kritis yang konsisten yaitu pada tahap tertinggi, strategies and tactics.

\section{SIMPULAN}

Kemampuan berpikir kritis subjek FD mencapai pada tahap akhir yaitu strategies and tactics, dari ketiga soal yang diberikan subjek mampu melampaui semua tahapan berpikir kritis, sehingga subjek FD memiliki kemampuan berpikir kritis yang konsisten. Kemampuan berpikir kritis subjek $A B$ berada pada tahapan yang berbeda pada setiap butir soal yang diberikan. Pada soal nomor 1 subjek mampu melalui 5 tahapan berpikir kritis dengan baik. Soal nomor 2 subjek hanya melampaui tahapan advanced clarification dan pada soal nomor 3 subjek hanya sampai pada tahap basic support. Kemapuan berpikir subjek EK, berada pada tahapan yang berbeda, pada soal nomor 1 dan 3 subjek berada pada tahapan basic support dan pada soal nomor 2 berada pada tahapan advanced clarification.

Hasil penelitian ini memberikan gambaran kepada guru dan kepada peneliti tentang kemampuan berpikir kritis siswa SMP Kelas VII pada materi pecahan. Diharapkan dengan mengetahui tingkat kemampuan berpikir kritis siswa, guru dan peneliti dapat merancang dan mengembangkan pembelajaran yang memfasilitasi siswa untuk berlatih berpikir kritis khususnya dengan memberikan soal dengan tipe open-ended sehingga dapat 
melatih siswa untuk berpikir terbuka dan kritis. Guru sebaiknya dalam setiap pembelajaran melibatkan siswa untuk berpikir kritis, memberikan soal tipe openended dan memantau kemampuan berpikir kritis siswanya sehingga dapat merancang pembelajaran yang sesuai.

\section{DAFTAR PUSTAKA}

Hidayanti, Dwi. 2016. Analisis Kemampuan Berpikir Kritis Siswa Smp Kelas IX Pada Materi Kesebangunan. Prosiding Konferensi Nasional Penelitian Matematika dan Pembelajarannya (KNPMP 1), Diselenggarakan oleh Program Studi Pendidikan Matematika, UMS, 12 Maret 2016

Hikmawati, Rully. 2013. Keefektifan Strategi Pembelajaran TTW (Think Talk Write) Berbantuan LKDP terhadap Kemampuan Berpikir Kritis Peserta Didik Kelas X. Skripsi diterbitkan oleh Universitas Negeri Semarang

Johnson, E. B. 2010. Contextual Teaching and Learning Menjadikan Kegiatan Belajar Mengasikkan dan Bermakna. Bandung: Kaifa Learning

Mina, E 2006. Pengaruh Pembelajaran Matematika Dengan Pendekatan Open-Ended Terhadap Kemampuan Berpikir Kreatif Matematika Siswa SMA. Bandung.Tesis pada PPs UPI. Bandung : Tidak Dipublikasikan.

Ennis, R. 1995. Critical Thinking. New Jersey: Prentice Hall

Nurannisa, E. 2013. Efektifitas Open Ended APPROCH Meningkatkan Kreativitas Siswa Dalam Memecahkan Masalah Matematika.
Sanjaya, Wina. 2103. Penelitian Pendidikan Jenis, Metode, dan Prosedur. Jakarta : Prenada Media Group.

Santrock, John, W. 2104. Psikologi Pendidikan Edisi 5 buku 2. Jakarta; Salemba Humanika

Shimada, S, dan Becker J.P. 1997. The Open-Ended Approach: A New Proposal for Teaching Mathematics. Virginia: National Council of Teachers of Mathematics.

Suherman, E, dkk. 2001. Strategi Pembelajaran Matematika Kotemporer. Bandung. Jurusan Pendidikan Matematika FPMIPA UPI

Sugiyono. 2010. Metode Penelitian Pendidikan Pendekatan Kuanti-tatif, Kualitatif dan R\&D. Bandung. Alfabeta.

Takahashi, Akihiko. 2006. Communication as Process for Students to Learn Mathematical.

[Online].Tersediahttp://www.criced.t sukuba.ac.jp/math/apec/apec2008/pa pers/PDF/14

Akihiko_Takahashi_USA.pdf.

(Diunduh pada 11 Desember 2016)

Wicaksono, H. N. 2013. Analisis Kesalahan Siswa Kelas V SD Negeri 2 Pada Pokok Bahasan Soal Cerita Pecahan Semester II Tahun Ajaran 2012/2013. Skripsi. Universitas Kristen Satya Wacana. http://repository.uksw.edu/handle/12 $3456789 / 3640$ (Diunduh pada 28 Juni 2016) 